


\section{The shifting border}

\section{MANCHESTER 1824}

Manchester University Press 


\title{
CRITICAL POWERS
}

\author{
Series Editors: \\ Antony Simon Laden (University of Illinois, Chicago), \\ Peter Niesen (University of Hamburg) and \\ David Owen (University of Southampton).
}

Critical Powers is dedicated to constructing dialogues around innovative and original work in social and political theory. The ambition of the series is to be pluralist in welcoming work from different philosophical traditions and theoretical orientations, ranging from abstract conceptual argument to concrete policy-relevant engagements, and encouraging dialogue across the diverse approaches that populate the field of social and political theory. All the volumes in the series are structured as dialogues in which a lead essay is greeted with a series of responses before a reply by the lead essayist. Such dialogues spark debate, foster understanding, encourage innovation and perform the drama of thought in a way that engages a wide audience of scholars and students.

\section{Published by Bloomsbury}

On Global Citizenship: James Tully in Dialogue Justice, Democracy and the Right to Justification:

Rainer Forst in Dialogue

\section{Published by Manchester University Press}

Cinema, democracy and perfectionism: Joshua Foa Dienstag in dialogue

Democratic inclusion: Rainer Bauböck in dialogue

Law and violence: Christoph Menke in dialogue

Forthcoming from Manchester University Press

Autonomy gaps: Joel Anderson in dialogue

Toleration, power and the right to justification:

Rainer Forst in dialogue 


\title{
The shifting border
}

\section{Legal cartographies of migration and mobility}

\author{
Ayelet Shachar in dialogue
}

\author{
Ayelet Shachar \\ with responses from: \\ Sarah Fine \\ Jakob Huber \\ Chimène I. Keitner \\ Noora Lori \\ Steffen Mau \\ Leti Volpp
}

Manchester University Press 


\title{
Copyright (๑) Manchester University Press 2020
}

While copyright in the volume as a whole is vested in Manchester University Press, copyright in individual chapters belongs to their respective authors, and no chapter may be reproduced wholly or in part without the express permission in writing of both author and publisher.

\author{
Published by Manchester University Press \\ Altrincham Street, Manchester M1 7JA \\ www.manchesteruniversitypress.co.uk \\ British Library Cataloguing-in-Publication Data \\ A catalogue record for this book is available from the British Library
}

ISBN 9781526145314 hardback

First published 2020

The publisher has no responsibility for the persistence or accuracy of URLs for any external or third-party internet websites referred to in this book, and does not guarantee that any content on such websites is, or will remain, accurate or appropriate.

Typeset by

Sunrise Setting Ltd, Brixham 